\title{
От Уэльса до Варшавы и далее: стратегическая адаптация НАТО к возрождению России на восточном фланге Европы
}

\section{Мариуш Фрыи}

Бюро национальной безопасности, Варшава, Польша, http://en.bbn.gov.pl/

Резюме: Незаконная аннексия Крыма весной 2014 года драматическим образом изменила восприятие безопасности и увеличила беспокойство в Восточной Европе, даже среди стран-членов НАТО. НАТО быстро отреагировало, приняв План действий по обеспечению готовности, трансформировав Силы реагирования НАТО и решив создать центры по командованию и управлению, или подразделения по интегрированию вооруженных сил НАТО (ПИВСН) в шести странах на своем восточном фланге. В свете предстоящего саммита в Варшаве, автор доказывает, что, несмотря на такие серьезные меры по обеспечению безопасности, способности и действия НАТО все еще недостаточны для того, чтобы адекватно справиться с текущим уровнем неопределенности и вызовами в восточной части Европы и для того, чтобы вселить уверенность в своих членов. В этой статье рассматриваются требования и варианты для углубления ощущения безопасности среди восточных членов НАТО, которые сталкиваются с классическими военными и гибридными угрозами со стороны России. Акцент поставлен на развитие двунаправленной стратегии сдерживания основанной на наказании и на отказе в доступе, путем поддержки укрепления военной инфраструктуры принимающей стороны, усовершенствования принятия оперативных решений через усиление ВГК ОВС НАТО в Европе, и усилением сотрудничества с Европейским Союзом и балтийскими странами не-членами НАТО.

Ключевые слова: НАТО, европейская безопасность, гибридная война, стратегический риск, сдерживание, План действий по обеспечению готовности, ПИВСН, многонациональные формирования. 


\section{Введение}

30 марта 2016 года польский министр обороны объявил начало стодневного обратного счета до саммита НАТО в Варшаве, который, по всей видимости, будет иметь большое влияние на будущее Альянса. В то же время, в свете все более агрессивных действий возрождающейся России, направленных на ослабление западного единства, администрация США решила развернуть бронированную бригадную боевую группу в Европе в феврале 2017. Эта группа даст возможность обеспечить вынесенное вперед ротационное присутствие и поддержит сдерживание, осуществляемое НАТО, и таким образом придаст уверенность своим членам на восточном фланге. Со времени своего последнего саммита в Уэльсе в 2014 году НАТО существенно изменило свою политику, отойдя от простых уверений. Оно укрепило Силы реагирования НАТО (СРН) и региональные командные структуры, увеличило число учений и периодов подготовки и даже приняло решение расширить свое военное присутствие путем создания ротационного, многонационального компонента в составе бригады.

К сожалению, эти меры безопасности недостаточны, чтобы оправдать ожидания прибалтийских государств и Польши. В свете провокационных действий Российской Федерации, эти страны призывают к более сильному присутствию НАТО, выражающемся в создании постоянных военных баз на их территории. Для этих государств, предстоящий саммит НАТО, который состоится 8-9 июля 2016 года, вызовет, по всей видимости, только чувство неудовлетворения. Эти конкретные внутрисоюзные разногласия поднимают ряд правомерных вопросов в плане того, в какой степени НАТО смогло адаптироваться на стратегическом уровне к новой среде безопасности, которая изменилась в основном благодаря России в результате незаконной аннексии украинского Крыма. Встает вопрос и о том, что следует далее делать НАТО, чтобы укрепить чувство безопасности у своих восточных членов, которые сталкиваются как с классическими военными угрозами, так и с риском гибридных нападений.

\section{Гибридная война России с Украиной и Западом}

Аннексией Крыма в марте 2014 года Россия обозначила начало своей неоимпериалистической миссии и попытки добиться глобального влияния в качестве одной из бесспорных мировых суперсил. Москва натравила своего гибридного военного зверя на Украину и на Запад, воспринимая западный мир в качестве своего основного оппонента, бывший советский блок в качестве своей основной сферы влияния и НАТО в качестве стратегической угрозы своей национальной безопасности.

Россия воспользовалась слабостями Украины, конкретно ее трансатлантическими отношениями и солидарностью с центром тяжести западного могущества, и начала нападение на ее дух, физическую мощь и свободу действий. Россия освободила все тормоза, пытаясь добиться страте- 
гической победы путем использования как материальных, так и нематериальных, военных и невоенных, законных и незаконных, прямых и косвенных атак на Киев и Запад. Эта цель была достигнута без открытого применения существенной военной силы.

Используя институциональные слабые места и законные точки давления, исторические и этнические трения, а также свои финансовые и деловые возможности, российская гибридная стратегия оказалась успешной не только на Украине, но и на международном уровне. Это влияние было направлено и на собственное население России с целью консолидировать власть Кремля и обеспечить на национальном уровне легитимность политики и действий без каких-либо ограничений. Сохраняя варево враждебных действий ниже точки кипения конвенциональной войны, Москва продвигает как кинетические, так и некинетические линии операций, изматывая своего противника не через решительную битву в классическом военном смысле Клаузевица, а путем постепенного снижения морального духа. В число некинетических мероприятий входят: политическая индоктринация, тактика осады, конспиративные теории с примесью антисемитизма, навешивание определенным личностям ярлыка «нацистов», использование диаспоры и влияния православной церкви. В этой бескомпромиссной информационной борьбе Москва использует влияние государственных СМИ, онлайн «армии троллей», прокремлевские экстремистские нарративы политических движений, мозговые центры, антиглобалисткие группы и даже разные НПО.

В экономической сфере Россия начинает вести финансовую войну в форме валютных спекуляций и дестабилизации денежной системы, а также и торговую войну путем шантажа компаний и поставщиков энергии и манипулирования цен энергоносителей. В киберсфере Москва продолжает проведение своих кибератак против публичных и частных сетей критической инфраструктуры, а также продолжает свою кибершпионскую деятельность.

Кинетические действия Кремля осуществляются путем прямого применения военной тактики сдерживания, в том числе и развертыванием больших конвенциональных сил вдоль восточной границы Украины; осуществления агрессивных и провокационных вылетов авиации в европейское воздушное пространство (Балтика, Швеция, Финляндия, Польша); угрозы использования оружия массового уничтожения (размещения ядерного оружия в Крыму); организации «внезапных» учений большого масштаба или военных инспекций без предупреждения; постоянным муссированием информации о планах расположить новые оружейные системы в областях, граничащих со странами-членами НАТО (например, расположение системы «Искандер» - мобильной системы баллистических ракет малой дальности, способных нести ядерные боеголовки - в Калининградскую область), или об амбициозных планах модернизовать свои вооруженные силы. 
Не напрямую Москва развернула под прикрытием «военизированные прокси формирования», называемые «маленькими зелеными человечками» (российский военный личный состав, действующий без знаков различия и официальной принадлежности), для содействия пророссийским сепаратистам, проведения диверсий, актов саботажа и даже применения тактики терроризма, а также снабжения сепаратистов тяжелым военным оборудованием - танками, самоходной артиллерией и систем ПВО.

\section{Европейский контекст безопасности после незаконной аннексии Крыма Россией}

Молниеносная аннексия Крыма Россией и последовавший подъем пророссийских сепаратистских движений на юго-востоке Украины, спровоцированный и подкрепляемый Москвой, расшатали основания среды безопасности, установившейся в Европе после окончания Холодной войны. Открытая демонстрация силы застала западное сообщество и НАТО врасплох и поставила восточноевропейские члены в уязвимое положение.

Гибридная стратегия Москвы позволяет ей добиваться своих стратегических целей путем использования всех располагаемых средств могущества, и как регулярных, так и нерегулярных подразделений вооруженных сил в ограниченном масштабе и скрытным способом, таким образом удерживая уровень своих действий ниже порога международной войны и ниже порога, требуемого для провоцирования ответа со стороны НАТО. Риски, связанные со стратегией такого вида, дают восточноевропейским странам реальную причину для беспокойства. В этом отношении, такой конкретный нелинейный подход будет очень проблематическим в плане реакции НАТО, главным моментом в которой является достижение политико-военного консенсуса в Альянсе по вопросу, как реагировать коллективно на такую угрозу в случае необходимости. Они также считают, что последствия от неспособности добиться этого в худшем случае может привести к подрыву Статьи 5 Договора о НАТО.

Беспокойство о безопасности среди членов Альянса на его восточном фланге привело к усилению миссии воздушного патрулирования Альянса и развертывания ротационных сухопутных сил и сил для специальных операций в странах Балтики и в Польше. Благодаря этому обязательству, НАТО сумело усилить оперативную совместимость путем проведения учебных сборов и учений, продемонстрировало постоянную военную ангажированность США и показало свою готовность к выполнению Статьи 5 Вашингтонского договора. ${ }^{1}$

Несмотря на этот однозначный знак солидарности членов НАТО, ситуация с безопасностью не улучшилась. Это привело к выявлению ряда раз-

1 Senate Armed Services Committee, Statement of General Philip Breedlove, Commander U.S. Forces Europe, April 30, 2015, по состоянию на 17 июля 2016, http://www.armed-services.senate.gov/imo/media/doc/Breedlove_04-30-15.pdf. 
личий в отношении, политике и подходах разных государств перед лицом непредсказуемости России. Россия продолжает оказывать влияние в форме гибридного наступления, и тогда начинают проявляться различия даже между европейцами. Начинают появляться линии разлома в таких ключевых геополитических платформах, как Вышеградская группа и Веймарский треугольник. В некоторых случаях нежелание западных государств противопоставить себя нелинейным действиям России, а также их склонность фокусироваться на обеспечении своих внутренних интересов, особенно в экономическом плане, начинает подрывать европейскую солидарность и европейскую силу. Что важно, новый контекст безопасности еще раз выявил военную слабость Европы и ее неспособность дать уверенности своим членам без военной поддержки США. Это так же усилило желание членов НАТО на восточном фланге иметь значительное и постоянное военное присутствие США на своей территории.

Запад, в конце концов, в июле 2014 года успел наложить на Москву дипломатические, экономические и финансовые санкции в ответ на захват Крыма. Эти санкции были ужесточены в декабре 2014. ${ }^{2}$ Санкции начали способствовать осуществлению основной политической цели сдерживать поведение России путем наложения достаточных штрафов на российскую экономику при ограничении отрицательных макроэкономических последствий для США и Европы. ${ }^{3} \mathrm{~K}$ сожалению, все дипломатические решения, направленные на установление мира в восточной Украине, оказались недостаточными. К примеру, Минский протокол от сентября 2014, подписанный киевскими властями и пророссийскими сепаратистами, оговаривал прекращение огня и установление буферной демилитаризованной зоны, но не выполнялся с самого начала. В Ньюпорте, Уэльс, опять же в сентябре 2014, НАТО приняло решение осуществить значительные изменения в своей политике, способах действия и структуре сил для того, чтобы гарантировать, что сможет справиться эффективно с новыми вызовами безопасности и успокоить озабоченность по вопросам безопасности своих членов в Восточной Европе.

\section{Стратегическая адаптация НАТО: от политики успокоения к политике сдерживания}

На саммите был объявлен План действий по обеспечению готовности (ПДГ), который подробно расписывает осуществление необходимых мер

2 Robin Emmott and Dmitry Solovyov, "EU urges more countries to impose sanctions on Russia over Crimea," Reuters, March 18, 2016, по состоянию на 17 июля, 2016, http://www.reuters.com/article/us-ukraine-crisis-eu-crimea-idUSKCNOWK167.

3 "Remarks of Secretary Lew on the Evolution of Sanctions \& Lessons for the Future at the Carnegie Endowment for International Peace," United States Mission to the European Union, March 30, 2016, по состоянию на 17 июля 2016, http://useu.usmission.gov/speech33016.html. 
по обеспечению безопасности и обороны. Этот комплексный пакет разделен на меры по обеспечению гарантий и на меры по адаптации ${ }^{4}$ с целью усилить присутствие и военную активность Альянса в Восточной Европе и ввести существенные долгосрочные изменения в состоянии сил НАТО, позволяющие ему реагировать более быстро на будущие вызовы и угрозы. ${ }^{5}$ Кроме того, пакет требует осуществления фундаментального переустройства СРН. Чтобы сделать свои силы более гибкими и боеспособными, Альянс принял решение создать новые «ведущие» силы быстрого реагирования: Объединенную оперативную группу повышенной степени готовности (ООГПГ) с вынесенными вперед многонациональными командованиями (Подразделения по интеграции сил НАТО [ПИСН]), которые обеспечат задействование и развертывание сил на территории восточных членов НАТО. Предполагалось, что ООГПГ будет сформирована как боевая группа в составе бригады, состоящей из нескольких тысяч военнослужащих, включающей значительный сухопутный компонент, поддерживаемый подразделениями воздушных, морских и специальных сил. Она должна состоять из трех до пяти механизированных батальонов и быть готовой к действию в рамках пяти или семи дней. Один из батальонов в составе около 650 солдат должен иметь готовность к развертыванию в рамках двух или трех дней с момента получения приказа. ПИСН должны обеспечивать синхронизацию и принятие ООГПГ на восточноевропейской территории. Кроме этих обязанностей, на ПИСН будет возложено координирование учений и совместное планирование. Для обеспечения адекватной поддержки со стороны принимающего государства (ППГ) после развертывания, НАТО приняло решение улучшить инфраструктуру для позиционирования - аэродромы, порты и конкретные базы - для того, чтобы обеспечить беспрепятственное принятие ООПГП и СРН.

Меры по адаптации также включают повышение степени готовности штаба Многонационального корпуса «Северо-Восток» (МНК СВ) в Шчецине (Польша), а также усиление его роли в потенциальных операциях НАТО на восточном фланге. И последнее, члены НАТО приняли решение обновить планы на случай чрезвычайных ситуаций в Восточной Европе. Они так же пришли к согласию остановить уменьшение расходов на оборону и постепенно увеличивать их до достижения $2 \%$ от ВВП в течении следующих десяти лет. Все предпринятые контрмеры должны подчеркнуть желание не только усилить способности НАТО для коллективной обороны, но и усовершенствовать механизм кризисного менеджмента.

Реализация мер по гарантированию включает поддерживание Альянсом увеличенного числа истребителей для воздушного патрулирования над прибалтийскими государствами и размещение реактивных истребите-

4 “NATO's Readiness Action Plan," Fact Sheet, May 2015, по состоянию на 17 июля 2016, www.nato.int/nato_static_fl2014/assets/pdf/pdf_2015_05/20150508_1505Factsheet-RAP-en.pdf.

5 Там же. 
лей в Польше и Румынии. В то же время вдоль восточных границ продолжаются регулярные миссии по наблюдению, осуществляемые Воздушной системой раннего предупреждения и управления (АВАКС). Усиленные военно-морские силы начали патрулирование Балтийского, Черного и Средиземного морей. Выполняя меры по гарантированию, к концу 2014 года НАТО усовершенствовало свою стратегию кризисного менеджмента и увеличило интенсивность сборов по подготовке и учений для коллективной обороны. Тем временем инициативы, осуществляемые отдельными государствами и на совместном уровне, тоже начали способствовать реализации пакета НАТО по гарантированию. США предоставляют существенную поддержку в этой области. Их Европейская инициатива поддержки (ЕИП) была задумана как средство для гарантирования безопасности членов НАТО и других партнеров НАТО, которые чувствуют себя под угрозой в результате действий России. Инициатива включает расширение военного присутствия США в регионе, интенсификацию двусторонних и многосторонних учений и сборов по подготовке, усовершенствование необходимой инфраструктуры, расширение предварительно размещенного американского оборудования и усиление работы по созданию партнерского потенциала. ${ }^{6}$ В декабре 2014 года Конгресс США одобрил финансирование программы в объеме 810 миллионов долларов, а также выделение дополнительных 175 миллионов для военной помощи Украине и балтийским государствам. ${ }^{7}$ К 2015 году НАТО сформировало временную ООГПГ. Под руководством Германии, Нидерландов, Норвегии и при поддержке других союзников группа прошла через ряд учений и оценок.

В январе и феврале 2015 года Союзники уточнили общую концепцию ООГПГ. В апреле и июне 2015 года в ходе учения под названием «Благородный прыжок» НАТО оценило способность ООГПГ осуществлять развертывание в короткие сроки в ответ на развивающийся кризис. Тогда, в октябре и ноябре 2015 года, в ходе маневров «Сход трезубца» союзники продемонстрировали способность ООГПГ осуществлять развертывание в рамках нескольких дней на всей территории Альянса.

Несмотря на факт, что НАТО активно осуществляло контрмеры как по адаптации, так и по гарантированию безопасности, отсутствие существенного улучшения ситуации с безопасностью в Балтийском регионе заставило власти Литвы, Латвии и Эстонии в мае 2015 потребовать от ВСК в Европе создать ротационное формирование в составе бригады на их территории в качестве сдерживающей силы против России. Хотя было принято официальное решение по этому вопросу, в июне 2015 министры обороны НАТО решили усилить СРН, численность которых сейчас достигла сорока тысяч по сравнению с прежними тридцатью тысячами. Кроме того, они

6 European Reassurance Initiative - Department of Defense Budget Fiscal Year (FY) 2016, Feb. 2015, по состоянию на 17 июля 2016, http://comptroller.defense.gov/ Portals/45/Documents/defbudget/fy2016/FY2016_ERI_J-Book.pdf.

7 Там же. 
предоставили ВКС в Европе новые полномочия по предварительной подготовке сил, которые могут быть развернуты в случае потенциального кризиса, таким образом максимизируя их готовность. И последнее, они обязали МНК СВ достичь полной оперативной способности в качестве главного штаба сил повышенной готовности ко времени следующего саммита НАТО, а также достичь способности координировать функции ПИСН и осуществлять командование ООГПГ.

К сентябрю 2015 все шесть ПИСН были активированы, и была поставлена цель достигнуть оперативной готовности до саммита в Варшаве. Совместное командование сил (СКС) в Неаполе приняло на себя управление ПИСН в Бухаресте и в Софии, а ПИСН в Риге, Таллине, Вильнюсе и Быдгоще были подчинены МНК СВ.

В декабре 2015 года армия США начала транспортировку комплектов оборудования, известных под названием Комплекты для деятельности в Европе (КДЕ), в первые вынесенные вперед объекты в Болгарии, Румынии и Литве. Оборудование, используемое региональными сухопутными войсками для подготовки и проведения учений с союзниками в рамках операции «Союзная решительность» в итоге будет складировано в семи местах в Восточной Европе. ${ }^{8}$

Также в декабре 2015 года, из-за экспансии российского военного потенциала в регионе Черного моря и милитаризации аннексированного Крыма, НАТО сформировало Мультинациональную дивизию «Юго-Восток» (МНД ЮВ) со штабом в Румынии. Это дополнение предназначено для обеспечения командования союзных сил, расположенных в юго-восточной части Европы.

Встреча министров обороны стран НАТО в феврале 2016 года привела к усилению восточного фланга Альянса. Они приняли решение расширить военное присутствие в этой области сформированием многонациональных сил на ротационной основе. Не было особого желания размещать силы на постоянной основе, и военные планировщики НАТО начали просчитывать размер и структуру необходимых войск и то, как осуществлять их ротацию на территории и вне территории восточноевропейских членов НАТО. ${ }^{9}$

Эти решения министров последовали за объявлением администрацией США за неделю до этого планов по увеличению расходов на ЕИП до уровня в четыре раза более высокого, чем в 2016 году, ожидающего одобрения 3.4 миллиардов долларов из бюджета на оборону за 2017 финансовый

8 "Tanks, heavy vehicles to be fully positioned in Eastern Europe next year," Stars and Stripes, December 10, 2015, по состоянию на 17 июля 2016, www.stripes.com/ news/europe/tanks-heavy-vehicles-to-be-fully-positioned-in-eastern-europe-nextyear-1.383125.

9 "NATO ministers approve new reinforcements for eastern Europe," MailOnline, February 10, 2016, по состоянию на 19 июля 2016, www.dailymail.co.uk/wires/ap/ article-3440315/NATO-chief-expects-OK-greater-forward-presence.html. 
год. ${ }^{10}$ Если это финансирование получит одобрение, последует расширение ротации войск и увеличение числа учений в Европе благодаря факту, что приблизительно 2.8 миллиардов из бюджета предназначены для армии США в Европе. ${ }^{11}$ За счет этого финансирования Сухопутные силы США планируют развернуть дополнительную боевую группу в составе бронированной бригады на ротационном принципе на европейском театре в феврале 2017 года и усилить предварительно позиционированное оборудование, чтобы обеспечить наличие одного комплекта боеготового оборудования для поддержки еще одной бронированной бригады на случай ее развертывания, а также на случай развертывания дивизии. ${ }^{12} \mathrm{~K}$ концу 2017 Сухопутные силы США планируют обеспечить постоянное присутствие в Европе трех полностью укомплектованных бригадных боевых групп. $^{13}$

Осуществленные меры по гарантированию безопасности и по адаптации существенно способствовали успокоению озабоченности восточноевропейских членов НАТО. Расширенные учения НАТО, проведенные НАТО в течение 2015 года, ${ }^{14}$ возымели ожидаемый эффект, и будут продолжены в 2016 году. Основной инструмент для реагирования НАТО, СРН, подвергся существенному усовершенствованию. Охватывая три отдельные элемента, СРН были укреплены созданием объединенной оперативной группы повышенной готовности в качестве их ядра, что позволило использовать их способность реагировать и достичь максимальной скорости ответа и оперативной маневренности. Концепция ООГпг должна быть испытана на

$10 \mathrm{Jim}$ Garamone, "Gorenc Discusses European Reassurance Initiative, Air Police Mission," U.S. Department of Defense, April 5, 2015, по состоянию на 17 июля 2016, http://www.defense.gov/News-Article-View/Article/713722/gorenc-discusseseuropean-reassurance-initiative-air-police-mission.

11 Senate Armed Services Committee, Statement of General Philip Breedlove, Commander U.S. Forces Europe, March 1, 2016, http://www.armed-services.senate.gov/ $\mathrm{imo/media/doc/Breedlove \_ 03-01-16.pdf.}$

12 "Eucom announces European reassurance initiative implementation plan," Eucom Live, March 30, 2016, по состоянию на 17 июля 2016, http://eucom.dodlive.mil/ 2016/03/eucom-announces-european-reassurance-initiative-implementation-plan/.

13 Две из них уже постоянно расположены в Западной Европе (бригада «Страйкер» и воздушно-десантная бригада).

14 В число основных учений за 2015 год входят: «Joint Warrior» (11-23 апреля: военно-морское учение в Северном Атлантике, 13000 участников); «Dуnamic Mongoose» (4-15 мая: учение по борьбе с подлодками у берегов Норвегии, 5000 военнослужащих); «Baltops» (5-20 июня: военно-морское и амфибийное учение в Балтийском море, 4500 военнослужащих); "Sabre Strike» (8-19 июня: наземное учение в прибалтийских государствах и Польше, 3000 военнослужащих); «Noble Jump» (10-21 июня: первый тест по развертыванию новых сил повышенной готовности в Польше, 2100 военнослужащих); «Trident Joust» (1728 июня: штабное учение в Болгарии, Румынии и Италии, 1500 военнослужащих) и "Trident Juncture» (21 октября-6 ноября: Италия, Португалия и Испания, 25000 военнослужащих). См. “NATO’s Readiness Action Plan. Fact Sheet." 
практике до достижения статуса полной оперативной готовности в ходе ряда таких учений в 2016 году, как «Brilliant Jump», «Trident Joust» и «Brilliant Capability». ${ }^{15}$ «Brilliant Jump» будет окончательным экзаменом для ООГПГ прямо перед саммитом НАТО. Ее оперативный статус должен быть продемонстрирован развертыванием группы в восточных странах-членах HATO.

Как только появятся первые признаки кризиса, СРН, поддерживаемые сетью новых штабов (МНК СВ, МНД ЮВ, ПИСН), размещенных на восточной территории Альянса, будут в состоянии быстро развернуть и включить войска в боевые действия, чтобы выполнить задачу коллективной обороны. ${ }^{16}$ К 2018 году МНК СВ будет в состоянии осуществлять командование СРН и вести широкомасштабные комбинированные оборонительные операции на северо-восточном фланге Альянса. Ожидается, что все шесть ПИСН достигнут статуса полной оперативной готовности до проведения предстоящего саммита НАТО. ${ }^{17}$ После этого должны быть созданы два дополнительных ПИСН - в Словакии (2016) и в Венгрии (2017). ${ }^{18}$ Решения, касающиеся подчинения сил МНД ЮВ, должны быть приняты после саммита в Варшаве. ${ }^{19}$ Это командование должно достичь начальной оперативной готовности в 2016, и полной оперативной готовности в 2018 году. Ожидается, что объекты в Польше, Эстонии и Латвии, являющиеся частью концепции ЕИП, будут в наличии в 2016, дополненные сооружениями в Венгрии к 2017 году. $^{20}$

Все эти действия и контрмеры, осуществленные НАТО, в некоторой степени смогли восстановить единство и солидарность Альянса и существенно успокоить его уязвимых восточных членов перед лицом потенциальных классических вооруженных угроз и гибридных действий со стороны России. Однако, до тех пор, пока Россия следует своей нео-империалистической стратегии и испытывает надежность НАТО, озабоченности восточных членов НАТО, особенно прибалтийских государств, остаются без полного ответа.

15 “NATO Response Force (NRF) Fact Sheet," по состоянию на 17 июля 2016, https://jfcbs.nato.int/page5725819/nato-response-force-nrf-fact-sheet.

16 "Projecting Stability: Charting NATO's Future. Speech by NATO Secretary General Jens Stoltenberg to the Atlantic Council, Washington, D.C.," April 6, 2016, по состоянию на 17 июля 2016, www.nato.int/cps/en/natohq/opinions_129758.htm.

17 NATO Force Integration Units (NFIU), по состоянию на 17 июля 2016, https://jfcbs.nato.int/page5725819/nato-force-integration-units.

18 "NATO Response Force (NRF) Fact Sheet."

19 Tadeusz Wróbel, "Sojusz w Bukareszcie," Polska Zbrojna.pl, December 10, 2015, по состоянию на 17 июля 2016, www.polska-zbrojna.pl/home/articleshow/17942?t= Sojusz-w-Bukareszcie.

20 "Tanks, heavy vehicles." 


\section{Ответ России на стратегическую адаптацию НАТО}

Все предпринятые НАТО действия для гарантирования безопасности своих восточных союзников воспринимаются Москвой как «ползучее расширение» НАТО в Восточной Европе: расширение, которое надо остановить. В результате этого, ситуация с безопасностью в этом регионе все еще преобладающим образом определяется и формируется политикой и действиями России, которые в высшей степени неоднозначны и непредсказуемы. Кремль продолжает использовать нелинейную, гибридную стратегию, которая в некоторой степени, похоже, является антитезисом комплексного подхода к военным операциям, применяемого Западом. Применяя все наличные силовые методы (политические, экономические, военные, информационные и т.д.), Москва сохраняет уровень напряженности/агрессии ниже порога войны, используя войска в качестве инструмента сдерживания или в ограниченном масштабе и косвенным образом, что позволяет России добиваться достижения своих стратегических целей. Россия запугивает международное сообщество, угрожая напряженностью, провоцируя и эскалируя напряженность не только в Восточной Европе, но и по всему миру, и что важно, постоянно манипулирует международным общественным мнением, приписывая последствия своих действий Западу.

Несмотря на ухудшающуюся экономическую ситуацию в стране, на последствия долгосрочных западных санкций и на снижение цен на нефть и газ, все еще наблюдается сильная политическая решимость укреплять свой военный потенциал и повышать свою боевую готовность. Российские военно-воздушные силы продолжают постоянно нарушать воздушное пространство суверенных государств на восточном и южном фланге Альянса, что приводит к ненужным инцидентам, даже провоцирует международные кризисы и порождает значительный риск открытой конфронтации, как случилось в ноябре 2015 года, когда Турция сбила российский военный самолет.

К примеру, в Калининградской области России удалось расширить свой потенциал преграждения доступа/блокирования зоны (A2/AD) и свой экспедиционный потенциал. ${ }^{21}$ Это позволяет Москве препятствовать любой попытке Альянса осуществления доступа по воздуху или по морю в этот регион, и даже отрезать прибалтийские государства от поддержки НАТО путем блокирования единственного наземного маршрута поставок из Польши, а именно Сувальского перешейка. Ограничение контр наступательных военных способностей прибалтийских государств позволило Москве занять положение, из которого она могла бы потенциально осуще-

${ }^{21}$ A2/AD способности охватывают наиболее современные противовоздушные мобильные системы (С-400 «Триумф»/ СА-21 «Ворчун» с оперативным радиусом действия до 400 км) и двойного назначения (конвенциональные и ядерные) мобильные системы баллистических ракет малого радиуса действия («Искандер-М»/СС-26 «Камень» с оперативным радиусом действия до 500 км). 
ствить быстрый захват территории с использованием приблизительно двадцати двух батальонов Западного военного округа и Калининграда. ${ }^{22}$ Такой сценарий может поставить НАТО в такое положение, в котором ему придется вести очень тяжелую, дорогостоящую и времяемкую контр наступательную операцию.

Москва намеренно поддерживает конфликт в Восточной Украине в замороженном состоянии, эскалируя и де-эскалируя напряженность по своему усмотрению. После относительно спокойного периода в начале 2016 года военная активность в Донбассе снова существенно увеличилась. ${ }^{23}$ Россия все еще осуществляет поддержку сепаратистов, обеспечивая командование и управление, огневую поддержку, поставку беспилотных летательных аппаратов (БЛА), коммуникаций и ракетных систем земля-воздух. $^{24}$ Поддерживая территории, оккупированные пророссийскими сепаратистами, в состоянии неопределенности, Москве удается сохранять стратегическую маневренность, необходимую для оказания давления на Киев и на Запад.

Согласно ВГК ОВС НАТО в Европе, Россия намеренно использует поток сирийских беженцев для дестабилизации Европы и для истощения ее ресурсов по оказанию гуманитарной помощи и социального обеспечения. Вмешательство России в сирийский конфликт существенно изменило динамику войны, став причиной перемещения более полумиллиона сирийцев с сентября 2015 года. Ожидается, что кризис с беженцами будет и дальше эскалировать, дестабилизируя еще больше среду безопасности в Турции, Европейском Союзе и НАТО. Однако, кризис так же позволяет России консолидировать свое влияние на Запад и использовать свое положение для переговоров в будущем.

Россия планирует в 2016 году еще больше увеличить свой военный потенциал и улучшить состояние вооруженных сил. Из-за динамически меняющейся и неопределенной ситуации в непосредственной близости от Москвы, последняя намеревается предпринимать существенные оборонительные контрмеры. Москва хочет улучшить состояние своих способностей для ядерного сдерживания путем развертывания новых систем «ядерной триады» и улучшения эффективности ее системы предупреждения о ракетном нападении. В состоянии постоянной боевой готовности должны

22 Согласно докладу корпорации РЭНД, чтобы дойти до Риги или Таллина, российским силам потребуются от 36 до 60 часов. См. David A. Shlapak and Michael V. Johnson, Reinforcing Deterrence on Nato's Eastern Flank (RAND Corporation, 2016), по состоянию на 17 июля 2016, www.rand.org/content/dam/ rand/pubs/research_reports/RR1200/RR1253/RAND_RR1253.pdf.

23 "Department of Defense Press Briefing by Gen. Breedlove in the Pentagon Briefing Room," U.S. Department of Defense, March 1, 2016, по состоянию на 17 июля 2016, www.defense.gov/News/News-Trans/Tran-View/Article/683817/department24 of-defense-press-briefing-by-gen-breedlove-in-the-pentagon-briefing.

Там же. 
находиться не менее 95 процентов ее ядерных сил. Число испытательных пусков межконтинентальных баллистических ракет удвоится до шестнадцати по сравнению с восемью в 2015.

Одной из приоритетных областей усиления являются боевые части и соединения Западного, Юго-западного и Арктического военных округов. Сухопутные силы должны сформировать четыре дополнительные дивизии на базе существующих бригад. Три из них, по всей видимости, будут развернуты в Западном военном округе, и одна в центральном. Тем временем будет продолжаться проведение внезапных проверок боевой готовности всех военных округов, видов вооруженных сил и родов войск. Боеготовность противовоздушной обороны должна быть на самом высоком уровне. Самими существенными маневрами российских вооруженных сил будут стратегические учения "Кавказ 2016», которые будут проведены в сентябре 2016 года. Они будут проводиться в Южном военном округе, на Северном Кавказе и в Крыму. Основной акцент будет поставлен на создание больших войсковых формирований и их развертывании на больших расстояниях. Боевой готовности и оперативности присвоен статус «высшего приоритета». Предположительно, российский Генеральный штаб бросил перчатку и поставил задачу, чтобы войска численностью в шестьдесят пять тысяч человек могли быть развернуты на расстоянии в три тысячи километров в течение семидесяти двух часов.

В 2016 году Москва так же продолжит осуществление интенсивной технической модернизации своих вооруженных сил. Современное оборудование должно составлять не менее 51 процента от всего оборудования, и уровень его эффективности должен достичь 92 процентов. Ожидается, что будут сформированы две бригады ракетных систем (Искандер-М и Торнадо-С) и одна бригада противовоздушных комплексов (Бук-МЗ), а шесть батальонов будут перевооружены новыми танками и боевыми машинами пехоты. Воздушно-космические силы получат двести новых и модернизованных летательных аппаратов, и пять полков ПВО будут перевооружены системами C-400. Военно-морским силам будут предоставлены две многоцелевые подлодки и семь надводных боевых кораблей. С помощью планов интенсивной модернизации такого масштаба Москва хочет сделать военно-промышленный комплекс двигателем развития всей национальной экономики и транспортной инфраструктуры.

Год за годом продолжает расти общественная поддержка антизападной политики Кремля. Как показывают опросы общественного мнения, увеличивается число людей, которые поддерживают увеличение расходов на оборону, если даже это и приводит к ухудшению экономического состояния страны. В 2013 году поддержка составляла 46 процентов, тогда как в 2015 она выросла до 53 процентов. Эта тенденция вряд ли повернет вспять, пока влияние российской информационной политики на свое собственное население останется на том же уровне интенсивности и размаха. 


\section{Потенциальные улучшения для стран восточного фланга НАТО}

Дорога НАТО от саммита в Уэльсе до саммита в Варшаве была длинной и трудной. Поначалу Альянс адаптировался к новой среде безопасности, расширив миссию патрулирования, затем начал проводить политику гарантирования безопасности и, в конце концов, остановился на усилении политики сдерживания. Благодаря осуществлению серии эффективных мер по гарантированию и адаптации, НАТО стало политически более единым, более гибким и боеготовым в военном отношении, и последнее, но не по значению, более убедительным в целом. Почти все стратегические цели, поставленные в Уэльсе, были достигнуты или находятся на пороге завершения временных графиков накануне саммита НАТО в Варшаве.

Однако, несмотря на упомянутые существенные достижения, НАТО должно продолжить процесс стратегической адаптации, если хочет быть на уровне будущих вызовов, классических или гибридных. Все еще есть ряд мероприятий, которые НАТО может осуществить для усиления состояния гарантирования безопасности и сдерживания на восточном фланге Альянса. Ниже перечислены двенадцать общих методов, над которыми стоит поразмышлять и которые стоить попробовать осуществить.

\section{1. Использование внутренней солидарности и стратегической}

\section{эмпатии}

До аннексии Крыма европейские союзники страдали от отсутствия стратегического консенсуса по вопросу о том, до какой степени НАТО должно фокусироваться на защите собственной территории и в какой степени государства-члены должны предоставлять свои ресурсы для экспедиционных операций. Благодаря действиям России, точки зрения членов НАТО как-то сблизились, хотя остаются различия в отношении восприятия стратегических вопросов, главным образом, что делать с Россией. Эти разногласия заметны не только на уровне правительств, но и на уровне общественности западных государств. В одном опросе общественного мнения, проведенного в прошлом году, 58 процентов немецких, 53 процента французских и 51 процент итальянских респондентов были против того, чтобы посылать их солдат для защиты таких членов НАТО, как Польша и прибалтийские государства, если на них нападет Россия. Тенденция в плане целостного общественного мнения вряд ли изменится. ${ }^{25}$ Отсутствие у НАТО последовательной стратегии в отношении России предположительно приведет к тому, что на Варшавском саммите союзники не достигнут согласия по тому, чего требуют восточноевропейские члены - создания постоянных

${ }^{25}$ Frayed Partnership. German public opinion on Russia (Gütersloh: Bertelsmann Stiftung, 2016), по состоянию на 17 июля 2016, http://www.bertelsmannstiftung.de/fileadmin/files/user_upload/EZ_Frayed_Partnership_2016_ENG.pdf. 
военных баз на их территории. ${ }^{26}$ Эта проблема требует от стран-членов опереться на внутреннюю солидарность и стратегическую эмпатию, чтобы лучше понять друг друга. Западноевропейские государства должны попытаться понять точку зрения стран-членов восточного фланга и отказаться от своей риторики в отношении этих стран как «буферной зоны» или стратегической глубины НАТО.

\section{2. Развитие двунаправленной стратегии сдерживания}

Чтобы дать восточным членам НАТО больше гарантий безопасности, Альянсу следует разработать двунаправленную стратегию сдерживания. Первое направление: стратегия, основанная на страхе от наказания, реактивная по своей сущности и функционирующая на основе предположения, что Запад/НАТО будут в состоянии победить противника в опустошительном контрнаступлении, включающим и потенциальный ядерный ответный удар. И по горячим следам: сдерживание через блокирование, про активное с самого начала, направленное на физическое затруднение возможностей противника атаковать, сделав общие потери от нападения более высокими, чем ожидаемые прибыли. ${ }^{27}$

Использование ядерной политики НАТО в качестве центрального фактора в основанной на страхе от наказания союзной стратегии сдерживания следует пересмотреть и актуализировать. Российская стратегия национальной безопасности в том виде, в котором она находится в 2015 году, не предполагает использования упреждающего ядерного удара. Применение этого средства предполагается только в качестве ответа на нападение на Россию или ее союзников с использованием ядерного оружия или другого оружия массового уничтожения (ОМУ), или в случае конвенциональной агрессии, угрожающей самому существованию государства. Однако, в настоящее время, Москва усиленно использует свою ядерную политику, чтобы довести до противника свое послание. Члены НАТО на его флангах имеют дело с бомбардировщиками (Ту-95), летающими вблизи их границ, которые могут нести ядерное оружие. Им подается информация о предстоящем развертывании тактических ракет (Искандер), которые могут быть вооружены ядерными боеголовками, в Калининградской области, или об ядерных элементах в конвенциональных учениях в Балтийском регионе. ${ }^{28}$

26 Judy Dempsey, “Judy Asks: Is NATO Doing Enough in Europe?" Judy Dempsey's Strategic Europe, March 23, 2016, http://carnegieeurope.eu/strategiceurope/?fa= 63093.

27 A. Wess Mitchell, "A Bold New Baltic Strategy for NATO," The National Interest, January 6, 2016, по состоянию на 17 июля 2016, http://nationalinterest.org/feature/ bold-new-baltic-strategy-nato-14818?page=3.

28 Michal Baranowski and Bruno Lété, NATO in a World of Disorder: Making the Alliance Ready for Warsaw (Washington, DC: The German Marshall fund of the United States, 2016), 10; http://www.gmfus.org/publications/nato-world-disorder-making-allianceready-warsaw. 
Эта тактика запугивания должна найти свою оценку в ядерной доктрине HATO.

Кроме того, с 2014 года США выражают озабоченность о соблюдении Россией Договора о ракетах средней и меньшей дальности (РСМД). ${ }^{29}$ Есть опасения, что российские крылатые ракеты попадают под ограничения Договора РСМД с радиусом действий от пятисот до 5500 километров, а потому, как и все ракеты такого типа, а также и пусковые установки для таких ракет, запрещены согласно положениям этого соглашения. Хотя Россия отрицает, что нарушения такого характера имеют место, НАТО должно продумать курс действий, касающихся деталей ответа в случае, если Россия выйдет из Договора о РСМД и развернет новые РСМД, которые позволят ей нападать, или угрожать нападением, на большинство европейских членов НАТО.

Сдерживание путем блокировки включает присутствие значительных вооруженных сил, осуществление концепции и наличие способностей для преграждения доступа/блокирования зоны A2/AD, а также реализацию подхода длительного сопротивления, выстраивающего приоритеты территориальной обороны, стратегии, способностей, структур и сил. Этот конкретный метод должен быть адаптирован и приведен к стандартам странами НАТО на восточном фланге, которые сталкиваются с агрессивной политикой России. Следует осуществить намерение формировать четыре новые дивизии для реализации способности вести интенсивные широкомасштабные военные операции на восточном фланге НATO, а также осуществить значительное улучшение по отношению к A2/AD способностям в сильно милитаризированной Калининградской области. ${ }^{30}$ Процесс разработки новой стратегии следует завершить пересмотром или актуализацией

29 Соединенные Штаты и Советский Союз подписали Договор о РСМД в декабре 1987 года. Они пришли к согласию запретить баллистические и крылатые ракеты наземного базирования с дальностью от 500 до 5500 километров. Это соглашение касается ракет как с ядерными, так и с конвенциональными боеголовками, но не относится к ракетам воздушного или морского базирования. См. Amy F. Woolf, Russian Compliance with the Intermediate Range Nuclear Forces (INF) Treaty: Background and Issues for Congress (Washington DC: Congressional Research Service, 2016), по состоянию на 17 июля 2016, https://www.fas.org/sgp/crs/nuke/R43832.pdf.

30 Основными российскими формированиями в Калининградской области (являющейся частью Западного военного округа) являются: Балтийский флот (56 кораблей, в том числе 2 класса «Кило» и 1 класса «Лада» подлодки, а также 3 фрегата, 2 эсминца, 26 корветов, 9 десантных кораблей и 12 минных тральщиков), 336-я бригада морской пехоты, 398-я отдельная воздушно-транспортная эскадрилья (Ан-2, Ан-12, Ан-24, Ан-26, Бе-12, Ми-8); 689-й отдельный полк морской истребительной авиации (Су-27); 4-й отдельный штурмовой авиационный полк (Су-24); 125-я отдельная вертолетная эскадрилья (Ми-8, Ми12); 396-я отдельная авианосная противолодочная вертолетная эскадрилья (Ка27); 79-я мотострелковая бригада, 7-й мотострелковый полк, 183-й береговой ракетный полк, 244-я артиллерийская бригада; 152-я ракетная бригада. 
Стратегической концепции НАТО. Изменения должны отражать доктрину НАТО, устранять недостатки планов действий в чрезвычайных ситуациях и уточнять оборонные планы НАТО.

\section{3. Наращивание наземных сил в Балтийском регионе}

Существование НАТО подвергается наибольшему риску именно в Балтийском регионе. Любой потенциальный конфликт с Россией в этом регионе поставит Запад/НАТО перед стратегической дилеммой: рискнуть включиться в широкомасштабную войну с ядерной сверхсилой или потерять доверие к себе. ${ }^{31}$ НАТО увеличило свое военное присутствие на восточном фланге Альянса путем создания многонациональных ротационных сил в виде бронированной бригады численностью от трех до пяти тысяч военнослужащих, и таким образом существенно улучшило состояние сдерживания. Учитывая, что ВГК ОВС НАТО в Европе считает, что соотношение сил в этом регионе составляет десять к одному в пользу России, ${ }^{32}$ ротационная бригада НАТО при ее нынешнем статусе, по всей видимости, недостаточна для адекватного сдерживания, и ее следует воспринимать как временное решение, требующее дальнейшего развития после саммита в Варшаве.

Европейские члены НАТО также должны понимать, что хотя США послали дополнительные бригадные боевые группы в Европу, это не является индикатором того, что их политика в сфере безопасности в отношении Европы изменилась. Их стратегия все еще крутится вокруг ограниченного, ротационного, вынесенного вперед присутствия и основана на стратегическом развертывании с американского континента в случае конфликта. ${ }^{33}$ Так же надо понимать, что ЕИП финансирует из годового бюджета, выделенного на операции США за границей, не имея своего постоянного бюджета. Это означает, что ЕИП не является долгосрочным решением проблем Восточной Европы. Скорее, это временное средство, которое может меняться со временем и сдвигаться в ту или иную сторону в соответствии со стратегическим контекстом безопасности. США также призвали восточных членов НАТО делать больше, чтобы обезопасить самих себя.

Стратегический дисбаланс сил в Балтийском регионе порождает опасность, что нехватка существенного присутствия войск, а также отсутствие необходимых оборонных способностей и военных сооружений может провоцировать Россию и далее подвергать проверке доверие к НАТО. Поэтому, если члены НАТО хотят осуществлять надежное сдерживание на уровне, достаточном для обескураживания потенциальных противников, они должны развернуть как минимум два ротационных боеготовых ком-

31 Baranowski and Lété, NATO in a World of Disorder.

32 Там же.

33 Artur Kacprzyk, "USA mobilizuje NATO do wzmocnienia wschodniej flanki," Polska Zbrojna, February 17, 2016, по состоянию на 17 июля 2016, http://www.polskazbrojna.pl/home/articleshow/18509?t=USA-mobilizuje-NATO-do-wzmocnieniawschodniej-flanki. 
понента в составе бригады - один в Прибалтике и один в Польше, поблизости от известного слабого места “Сувальского перешейка» ${ }^{34}-$ с долгосрочной целью располагать, по крайней мере, одной бригадой, постоянно расквартированной в Прибалтике.

\section{4. Обеспечение воздушного превосходства в северо-восточном углу НАTO}

В свете значительных A2/AD способностей России в Балтийском регионе НАТО следует сместить фокус своей воздушной доктрины от концепции воздушного патрулирования к комплексной противовоздушной обороне. Чтобы сохранить свое воздушное превосходство, оно должно перестроить противовоздушную оборону так, чтобы она включала многослойную, среднего радиуса действия и полностью интегрированную систему с истребительным компонентом, ракетным компонентом земля-воздух, системами разведки, наблюдения и рекогносцировки, а также с использованием космических активов. ${ }^{35}$ Это позволит НАТО проводить операции в высоком темпе ${ }^{36}$ и обеспечивать достаточную воздушную поддержку наземных сил. Чтобы выполнить эту задачу, балтийским государствам придется интенсифицировать процессы сотрудничества и модернизации на индивидуальном уровне путем приобретения авиационных ресурсов и ресурсов для противоракетной обороны. На уровне НАТО они также должны активно участвовать в таких «программах умной обороны», как противоракетная оборона НАТО, система наблюдения НАТО за наземной обстановкой и патрулирование воздушного пространства НАТО.

\section{5. Расширение поддержки военной инфраструктуры со стороны принимающего государства}

Члены НАТО на восточном фланге должны интенсифицировать свои усилия по усовершенствованию инфраструктуры, необходимой для обеспечения устойчивого позиционирования сил Альянса на территории восточных государств-членов НАТО и для защиты беспроблемного поступления подкреплений для предварительно развернутых в регионе сил. ${ }^{37}$ Эти члены должны инвестировать средства на развитие способностей для поддержки принимающего государства, военных сооружений, в том числе портов для воздушного и морского дебаркирования, складов и других объектов, необходимых для базирования и текущего обеспечения войск и их подготовки.

34 Baranowski and Lété, NATO in a World of Disorder.

35 Jim Garamone, "Gorenc Discusses European Reassurance Initiative, Air Police Mission," U.S. Department of Defense, April 5, 2016, по состоянию на 17 июля 2016, www.defense.gov/News-Article-View/Article/713722/gorenc-discusses-europeanreassurance-initiative-air-police-mission.

36 Там же.

37 "Department of Defense Press Briefing by Gen. Breedlove." 


\section{6. Предоставление полномочий на проведение учений НАТО без предварительного предупреждения}

Хотя Альянс интенсифицировал проводимые учения, «разрыв в учениях» между НАТО и Россией все еще имеет место, что касается масштаба и скорости. В феврале 2014, как раз перед аннексией Крыма, Россия мобилизовала 150000 военных под предлогом проведения антитеррористических учений. Многие из этих формирований затем были развернуты вдоль украинской границы, как раз тогда, когда Россия начала инвазию в Крым. В сентябре, в рамках учения «Восток-14», Россия задействовала 155000 военнослужащих. В то же время самые крупные учения НАТО, «Анаконда14» (октябрь) и "Дерзкий аллигатор-14» (октябрь-ноябрь), были проведены при участии 13250 и 15000 военнослужащих соответственно. Это несимметричное состояние следует нейтрализовать, сохраняя военные учения на самом высоком относительном уровне интенсивности. Второй проблемой, которую надо решать на уровне Альянса, является способность организовать «внезапные» военные маневры без предупреждения. В декабре 2014 года Москва без предупреждения начала неожиданное учение в Калининградской области с участием 9000 военных. ${ }^{38}$ Демонстрируя способность мобилизовать такое большое число людей настолько быстро, Москва дает основания для серьезной озабоченности со стороны центрально-европейских государств по поводу возможности нанесения ограниченного удара против их территорий. Хотя НАТО сохраняет свою политику прозрачности и в отношении своих военных учений, с учетом учений без предупреждения, проводимых Россией, властям Альянса следует принять решение об организации подобной деятельности, и если необходимо, проводить такие учения в качестве меры сдерживания.

\section{7. Предоставление ГВК ОВС НАТО в Европе полномочий на умень- шение времени реакции сил}

Молниеносная аннексия Крыма показала миру, что признаки конфликта или кризиса могут не быть заметны предварительно. Кроме того, каждое решение НАТО об ответной реакции основывается на консенсусе его членов, которым, в свою очередь, необходимо время для обсуждения и рассуждения. В результате, НАТО должно усовершенствовать процесс принятия решений, хотя бы на оперативном уровне. Хотя ГВК ОВС НАТО в Европе даны правомочия инициировать подготовку для развертывания ООГПГ, передвижение войск все еще зависит от политического руководства НАТО. Чтобы решить эту проблему эффективно и ускорить время реакции сил, государствам НАТО следует прийти к согласию предоставить ГВК ОВС НАТО в Европе больше полномочий, гибкости и ответственности. ГВК ОВС НАТО в

38 Ian J. Brzezinski and Nicholas Varangis, "The NATO-Russia Exercise Gap," Atlantic Council, February 23, 2015, по состоянию на 17 июля 2016, http://www.atlanticcouncil.org/blogs/natosource/the-nato-russia-exercise-gap. 
Европе должно не только готовить и активировать силы реагирования, но и развертывать их на театре военных действий НАТО, если это необходимо. Предоставление разрешения такого характера может поддержать политику сдерживания НАТО, иметь желаемые результаты на начальной фазе развития конфликта, ${ }^{39}$ и может позволить силам реагирования избежать ситуации, в которой они увязнут в боях без перспективных оперативных вариантов. ${ }^{40}$ И последнее, политические власти НАТО должны предоставить ГВК ОВС НАТО в Европе право проводить «внезапные» учения в качестве инструмента сдерживания.

\section{8. Интенсификация военного сотрудничества с балтийскими странами, которые не являются членами НАТО}

Партнеры НАТО, Швеция и Финляндия, дают очень ценный вклад в дело Альянса. Вооруженные силы обоих государств имеют впечатляющую историю в смысле сотрудничества и относительно высокую степень оперативной совместимости с НАТО. Швеция предоставила свои силы для участия в операции в Афганистане и свой воздушный компонент для Ливии. Ее силы принимают участие в СРН. То же самое относится и к Финляндии: силы этого государства принимали участие в операциях на Балканах и в Афганистане под руководством НАТО. В 2012 году Финляндия тоже предоставила свои войска для участия в СРН. Оба государства так же участвуют в разных многонациональных проектах в сфере безопасности и обороны, и они в одинаковой степени обеспокоены военным возрождением России. Вот почему НАТО должно поддерживать тесные отношения с этими двумя государствами в плане учений, учебных сборов и строительстве оборонных способностей. НАТО следует усовершенствовать процесс обмена информацией и разведывательными данными с этими двумя государствами и использовать текущий уровень оперативной совместимости. В плане совместного строительства способностей союзники должны поставить ударение на развитии таких активов, как разведка, рекогносцировка и наблюдение, средства для электронной борьбы и точечное участие. НАТО также надо усилить сотрудничество по таким вопросам, как борьба с пропагандой и дезинформацией, кибероборона и стратегические нарративы.

\section{9. Использование комплексного сотрудничества с ЕС для того, чтобы справляться с гибридными угрозами}

Говоря языком стратегии, невозможно укрепить восточный фланг НАТО без участия ЕС и его Общей политики безопасности и обороны. В резуль-

39 Sidney J. Freedberg, Jr., "Wargame Warns NATO Unready for Baltic Crisis," Breaking Defense, April 12, 2016.

40 Tomasz Kowalik, "NATO on the Right Path from Assurance to Deterrence," The German Marshall Fund of the United States, December 15, 2015, по состоянию на 17 июля 2016, http://www.gmfus.org/blog/2015/12/15/nato-right-path-assurancedeterrence. 
тате этого, саммит НАТО в Варшаве не должен затенять важность встречи Европейского Совета, который состоится в июне 2016, и который определит направление, в котором будет развиваться политика безопасности и обороны ЕС. Эти два стратегических компонента безопасности - ЕС и НАТО - должны взаимно усиливать и дополнять друг друга в плане действий, процедур, структур, компетентностей и способностей.

Новая Глобальная стратегия ЕС должна подчеркивать значение интегрированного, комплексного и синхронизированного сотрудничества с НАTO с упором на то, как справляться с гибридными угрозами и как реагировать на беженский и миграционный кризисы. В декабре 2017 года НАТО разработало проект антигибридной стратегии, которая позволит ему реагировать эффективно на нелинейные нападения. В настоящее время Альянс разрабатывает комплекс конкретных индикаторов раннего предупреждения, которые смогут инициировать ряд разных вариантов кризисного реагирования. ${ }^{41}$ НАТО следует пригласить ЕС для участия в этой работе для того, чтобы обмениваться знаниями, опытом и лучшими практиками. Это сотрудничество должно отличаться тем, что будет касаться таких невоенных элементов, как бизнес, финансы, СМИ, киберпространство или энергетика - все из которых являются важными вопросами и которые могут подвергнуться гибридным атакам. Обе организации должны подчеркивать важность кибербезопасности, стратегических коммуникаций, пограничного контроля, усиления обмена информацией и разведданными.

Тогда как Запад, по всей видимости, не может предложить настолько убедительный стратегический нарратив, как его оппоненты, ${ }^{42}$ ЕС и НАТО должны объединить свои уникальные способности и начать противодействовать дезинформации и пропаганде, выявлять ложь и мифы, которые приводят в смятение общественное мнение, усиливают социальную напряженность и подрывают доверие к государству.

\section{0. Демонстрация полной солидарности с южным флангом}

Восточные члены НАТО обязаны показать другим союзникам, что безопасность на их территории не может быть обеспечена без мира и стабильности в юго-восточной части Альянса или в других частях евроатлантического региона. Хотя само существование этих государств находится под угрозой со стороны России, они должны мобилизовать себя для того, чтобы гарантировать безопасность государств на юго-восточном фланге НАТО. В частности, как показывает нынешняя тенденция увеличения числа беженцев, прибывающих в Европу, эти государства должны быть готовы поддержать стабилизационные усилия в юго-восточной Европе, поддержать кампанию

\footnotetext{
41 Jamie Shea, "Resilience: a core element of collective defence," NATO Review Magazine, по состоянию на 17 июля 2016, http://www.nato.int/docu/review/2016/Alsoin-2016/nato-defence-cyber-resilience/EN/index.htm.

42 Dempsey, "Is NATO Doing Enough in Europe?"
} 
анти-ИГИЛ коалиции и в конечном итоге оказать поддержку по обеспечению безопасности Турции, если это неожиданно потребуется.

\section{1. Реализация обещания достичь оборонных расходов до уровня $2 \%$ ВВП}

В Ньюпорте было принято решение остановить сокращение оборонных расходов и постепенно повысить их уровень до ожидаемых $2 \%$ от ВВП в течение следующих десяти лет. Однако, выполнение этого решения очень далеко от поставленной цели. Хотя в 2015 году двадцать один союзник из всех членов или остановили снижение, или обратили тенденцию в оборонном инвестировании ${ }^{43}$ за год до саммита в Уэльсе, до десяти государств тратит на оборону менее одного процента ВВП и до шестнадцати государств тратят менее $1.2 \%$. В настоящее время только пять членов НАТО удовлетворяют отметке в 2\% (Эстония, Великобритания, Греция, Польша и США).

Поэтому маловероятно, что половина членов НАТО удвоят свой оборонный бюджет в течение следующих десяти лет, даже если предположить, что нынешние неблагоприятные условия безопасности в Европе сохранятся. Неспособность удовлетворить требованию достичь $2 \%$ расходов на оборону может иметь стратегические последствия для будущего Альянса. В краткосрочном плане, это может все больше раздражать власти США и оказать влияние на операционализацию ПДГ. В долгосрочном плане, это может оказать влияние и даже снизить политико-военные амбиции НАТО и существенно ограничить выполнение всего спектра миссий Альянса. Восточные члены НАТО, и в частности те, кто требует, чтобы НАТО развернуло постоянные гарнизоны на их территории, должны показать пример остальному Альянсу, удовлетворив требованию о $2 \%$.

\section{2. Возобновление конструктивного диалога с Россией}

Отношения между Западом/НАТО и Россией сейчас выглядят как ходьба по тонкому льду, и есть опасность, что гибридная война может прогрессировать в ограниченную конвенциональную войну. ${ }^{44}$ Чтобы остановить этот процесс, НАТО должно начать активный диалог с Россией. Благодаря своему участию в сирийском конфликте Россия успела, в некоторой степени, выйти из положения международной изоляции. Обеспечив себе критически важную роль в процессе разрешения ближневосточного конфликта, Россия успела приоткрыть дверь к нормализации отношений с Западом. Несмотря на заверения Генерального секретаря НАТО, что есть мало шансов на возвращение к «бизнесу, как обычно» в смысле сотрудничества с

43 Заявление генерала Филиппа Бридлава.

44 Frank Hoffman, The Contemporary Spectrum of Conflict. Protracted, Gray Zone, Ambiguous, and Hybrid Modes of War (Washington, D.C.: The Heritage Foundation, 2016), по состоянию на 17 июля 2016, http://index.heritage.org/military/2016/ essays/contemporary-spectrum-of-conflict/. 
Россией, $^{45}$ последнее заседание совета НАТО-Россия в апреле 2016 года, после почти двух лет молчания, дает сигнал, что НАТО хочет возобновить политический диалог с Москвой. Однако, надо отметить, что такие переговоры имеют смысл, только если НАТО ведет их с позиции силы. Москва всегда будет рассматривать дипломатию без одновременного сдерживания, как слабость НАТО/Запада, которая будет поощрять Кремль к продолжению своего нео-империалистического поведения. В результате, НАТО должно продолжить усиление военного присутствия Альянса на восточном фланге, в то же время принимая участие в дипломатических усилиях по выполнению Минского протокола в полном объеме, улучшению военной прозрачности и уменьшению потенциальных военных рисков.

\section{Выводы}

Укрепление Сил реагирования НАТО и более ощутимое присутствие Альянса, достигнутое путем создания ротационного мультинационального компонента в составе бригады, поддерживаемого распределенными командными центрами на восточном фланге НАТО, до сих пор всего лишь защищает безопасность наиболее восточных частей Альянса. Тенденции текущей российской политики и соотношение сил в регионе не оставляют никаких других возможностей, кроме как предположить, что налицо все еще высокая вероятность того, что Москва продолжит искать пути, в том числе и асимметрические методы, для разрушения международных механизмов безопасности, созданных НАТО и ЕС для гарантирования сегодняшней стабильности в Евроатлантическом регионе.

НАТО должно продолжить реализацию процесса стратегической адаптации: способности его противников постоянно и умело адаптироваться к новым условиям безопасности, как и их неугасающее желание подвергать испытанию надежность НАТО, не оставляют возможностей для иного курса действий. Для начала, Альянс должен использовать свою внутреннюю солидарность и стратегическую эмпатию, чтобы повысить внутрисоюзные гарантии. Оно должно разработать двунаправленную стратегию сдерживания, основанную на страхе от наказания и на отказе доступа. НАТО должно продолжить наращивание наземных сил в Балтийском регионе до двух ротационных боеготовых оперативных групп в составе бригады, с долгосрочной целью располагать хотя бы одной постоянно базированной бригадой в прибалтийских государствах. Альянс должен установить воздушное превосходство над Балтийским регионом и улучшить инфраструктуру принимающей страны, что позволит быстро принимать большие подкрепления от союзников. НАТО должно дать ГВК ОВС в Европе новые полномочия, в

45 Martin Banks, "'Business as Usual' With Russia Unlikely, NATO Leader Says," DefenseNews, April 11, 2016, по состоянию на 17 июля 2016, www.defensenews.com/story/defense/policy-budget/policy/2016/04/11/businessusual-russia-unlikely-nato-leader-says/82902184/. 
смысле ускорения времени реакции и проведения учений без предупреждения для того, чтобы гарантировать, что силы НАТО будут оставаться способными к ответу, и что политика сдерживания будет оставаться сильной. На международной арене Альянс должен интенсифицировать сотрудничество со странами Прибалтики, не являющимися членами НАТО, и комплексное сотрудничество с ЕС с целью успешно справляться с гибридными угрозами. Члены НАТО на восточном фланге должны продемонстрировать солидарность с членами НАТО на южном фланге, которые в данное время страдают от миграционного кризиса. Все государства должны показать свою готовность выполнить обязательство достичь $2 \%$ уровня оборонных расходов. И последнее, НАТО должно возобновить и провести конструктивный диалог с Россией с целью де-эскалировать текущую ситуацию с безопасностью. Все эти указания могут существенно способствовать гарантированию того, что НАТО сохранит эффективное и надежное состояние сдерживания и увеличит вероятность того, что в будущем Европа будет радоваться более надежной безопасности.

Поэтому предстоящий саммит в Варшаве следует рассматривать как конечный этап долгосрочного процесса адаптации НАТО к новым вызовам, порожденным агрессивным военным возрождением Российской Федерации. Альянс должен постоянно развиваться: действие - реакция - контрреакция должны продолжаться в бесконечном цикле. В качестве элемента стратегического процесса НАТО должно постоянно оценивать свою политику, стратегию, структуры, способности и силы. Стратегический сдвиг от гарантирования безопасности к усилению и затем к сдерживанию, начатый на саммите в Уэльсе, должен продолжаться и после завершения саммита в Варшаве.

\section{6 авторе}

Полковник Мариуш Фрыц, доктор философии, в настоящее время служит заместителем начальника Отдела военных анализов Департамента по надзору за вооруженными силами Бюро национальной безопасности Польши в Варшаве. 